\title{
Beyond Commerce: Women and Power in Traditional Nigerian
}

\author{
Market \\ Adebukola Foluke Osunyikanmi ${ }^{1^{*}}$ \\ ${ }^{1}$ Department of Political Science and Public Administration, Faculty of the Social and Management \\ Sciences, Adekunle Ajasin University, Akungba Ondo State, Nigeria \\ *Adebukola Foluke Osunyikanmi, E-mail: bukkyosunyikanmi@yahoo.co.uk
}

Received: November 28, 2016

Accepted: June 4, 2017

Online Published: June 6, 2017

doi:10.22158/wjssr.v4n2p175

URL: http://dx.doi.org/10.22158/wjssr.v4n2p175

\begin{abstract}
Powerlessness of women, gender inequality and discrimination against women are concepts that often dominate political discourse. These perspectives on relations between men and women critically trivialize the unique role of women in the socio-economic and political development of Africa.

The traditional market, a physical location where traders display and sell their wares, has always been under the dominance of women. Historically, legal and political structures were institutionalized in such markets with a view to protecting the interest of all trading members who were mainly women. In contemporary dispensation, they still use those structures to settle disputes among themselves and [also negotiate for amenities from their governments.

This paper, using primary and secondary data, examines the efficacy of the traditional legal, social and political institutions provided by the market; the extent to which the institutions have facilitated the inclusion of women in the political space; and measures that will help strengthen their effectiveness.
\end{abstract}

\section{Keywords}

power, women, market, development

\section{Introduction}

Markets are an integral part of all human societies. They serve to ensure orderliness as people engage in daily commercial transactions. Demand and supply are carried out in coordinated and cooperative manners. As platforms for the exchange of goods and services, markets are vital to the socio-economic lives of people all over the world.

Diverse meanings have been given by scholars to explain the concept of a market. In the word of Hodder and Ukwu (1969), a market is "an authorised public concourse of buyers and sellers of commodities meeting at a place or at an appointed time”. This definition presents a market as a place for buying and selling, adding that the place is authorised to allow unrestricted movement of people. 
Corroborating the idea that market evolves to give credence to the social contract that people enter into, Omole (2002) submits that markets are made by men for their use. Living in isolation is not in tune with the social and economic needs of man. Deriving from this point, it is clear that no household can source all its needs within its home. There is always the need to buy other people's products and sell one's surplus products. Flowing from this natural instinct, Ayittey (1991) opines that market creates the platform for exchanging surplus goods. According to Good (1976), markets are "specific sites where sellers and buyers assemble on appointed days to exchange goods and services, and to participate in a variety of social activities complementing routine business transactions."

The submission of Good on market gives a clear knowledge that a market can be defined as a place that is not only used for commercial activities but also for other socio-cultural and political activities. It emphasized the periodicity of market days. In essence, this was the practice of most traditional markets. Urbanization and growth in population led to the reversal of periodicity in most traditional markets in Nigerian communities.

Traditional market in Nigeria serves as the platform for sustainable economic growth for majority of the people in the informal sector. This sector accommodates several people who are mostly uneducated but seek self-employment. Traditional markets have characteristics that distinguish them from contemporary shopping malls and supermarkets. They play crucial roles in the economic survival of people especially women and their households (O’Brian, 1997). In patriarchal societies where women's rights are subordinated under men, traditional market provides the means for self-actualization for women. It gives opportunity for social groups to thrive as political discussions flowed easily in the course of carrying out economic activities in the market.

The surest way for the poor uneducated woman to survive and earn livelihood is by trading in a market. Although women might not be the vanguard of all activities in the market, yet women played some important roles in the development of Nigerian traditional market. An understanding of activities that take place in the market will help us analyze women's social, economic and political roles in the society.

Ikpe (1997) enumerated women of great virtue who distinguished themselves as leaders of market associations and moved on to become political colossus. He avers that women like Iyalode Efusetan Aniwura and Iyaloja Tinubu were renowned merchants and political figures; they stood shoulder to shoulder with their male counterparts in the political spheres. These women were so influential that kings had to consult them on social issues during their era.

Similarly, Madubuike and Solomon (2007) argued that one cannot forget the role played by the courageous Aba market women who dared the colonial regime. They protested against different colonial ordinances like the Native Revenue Ordinance which increased taxes payable by market women in eastern Nigeria. The most widespread and significant of these protests was the Aba Riots of 
1929 (Mba, 1989). These riots engulfed the whole of eastern Nigeria. The organizing abilities of the women in handling public and delicate matters were highly commendable. The capacity to plan and execute effectively, taking government by storm, demonstrated the leadership, dexterity, determination and power of women's collective action. Thus, by their agitation, women contributed greatly to the nationalist movements, and the eventual rise of the Nigerian nation. Despite great contributions of women to socio-political and economic development of the society, the society however did not pay keen attention to women's development which has gone a long way to dampen their morale and make their effort fruitless. Therefore, Lenin (1997) stressed the need for active involvement of women in the society as women are agents of change and development.

On this note, the core objective of this paper is to examine the efficacy of the traditional legal, social and political institutions provided by the market; the extent to which the institutions have facilitated the inclusion of women in the political space; and measures that will help strengthen their effectiveness.

\section{Methodology}

Basically, there are two major sources of data collection available to this paper. These are primary and secondary data. The primary sources of data were both qualitative and quantitative in nature. Some concerned women were interviewed. Questionnaires were also administered with the questions structured according to the objectives of the study. This is to elicit women's opinions on their participatory roles in the organization and management of their market; and how they can traverse this to the political sphere. To arrive at the selection of respondents, women of reproductive age were chosen using purposive sampling. The 300 questionnaires were distributed to the purposively selected women in the studied areas.

\subsection{The Studied Area}

The Federal Republic of Nigeria is on the Gulf of Guinea in West-Africa. It is bordered by Benin in the west, Cameroon in the east, Chad and Niger Republic in the north and the Atlantic Ocean in the south. Nigeria is divided into six geo-political zones namely South-South, South-East, South-West, North-East, North-West and North-Central.

\subsection{Population of the Study}

Three traditional markets will be examined in three selected states in Nigeria: Kano State in the North-West, Abia State in the South-East and Ondo State in the South-West. Women trading in the traditional markets of these states will serve as the sample population of the study.

\subsubsection{Kano State}

Kano State is one of the largest states in Nigeria having a population of 9,383,682 (2006 National Census). It has 44 local governments and occupies a land area of 204,479.6 square kilometer. Kano City, the state capital, is the largest commercial centre in northern Nigeria. The languages of commerce 
are English and Hausa.

\subsubsection{Ondo State}

Ondo State is located in the southwest of Nigeria. Akure is the state capital. The State has eighteen (18) Local Government Areas. Ondo State occupies a land area of 14,798.8 square kilometer. Its population is 3,460,877 (2006 National Census). The languages used for commercial transactions are English and Yoruba.

\subsubsection{Abia State}

Abia State is located in the southeast of Nigeria. The administrative capital is Umuahia while Aba serves as the major commercial centre. Its citizens are predominantly Igbo people. The state has 17 local governments occupying a land area of 5,834 square kilometers. The languages used for commerce are English and Igbo.

\section{Theoretical Framework}

Feminism can be defined as the movement aimed at establishing and defending equal political opportunities for women. Much has been written by proponents concerning the definition of Feminism. Nonetheless, the view that has aptly identified its outstanding tenets is that which links it to the social disabilities under which women live. To this extent therefore, Oliver Banks has defined feminism as a historical phenomenon which started from a sense of dissatisfaction with the conditions of women's lives and opportunities coupled with the beliefs that women's disabilities rise not from nature itself, nor indeed from any ills which afflict mankind but from the way in which women's desire and abilities have been subordinated to the needs, desire and interest of men.

Despite many strands of feminist theory that exist such as radical feminism, Marxian feminism, social and liberal feminism, this paper will adopt cultural feminism. Cultural feminist theory was developed from radical feminism, and theorists such as Margaret Fuller, Frances Willard, Jane Addams and Charlotte Perkins Gilman were the major proponents of the cultural feminist theory. The theory was initiated in 1845 by Margaret Fuller. Charlotte Perkins Gilman in 1898 made the first feminist sociological conceptualization of the distinction between biologically determined attributes and socially learned behavior where she created the concept of excessive sex distinction to refer to what we now mean by gender (Ritzer, 2008).

According to the cultural feminist theory, women naturally possess qualities that distinguish them from men; and that society is expected to be structured in order to benefit men and women. Thus, women are born with attributes of kindness and gentleness. Also, women are more disposed to ideas such as interdependence, cooperation, relationships, community, sharing, joy, trust and peace. They assume that the only difference between male and female is principally based on biological sexes and as such women can equally be represented in the political arena rather than been subordinated. To the cultural 
feminists, biological differences do not hinder women from participating in politics and if women are given a chance they can prove better in decision making. Moreover, cultural feminist theory commends the positive aspect of the female character, and recognizes the biological differences between men and women. Hence, to the cultural feminists, women are predisposed to be good leaders who would not lead the country into war; thus the world would be a better place if women should rule the world.

Cultural feminist theory argued that the traditional role of women provides the basis for the articulation of a more humane world view. They argued that in the governing of the state, society needed such women's virtues as cooperation, caring pacifism and nonviolence in the settlement of conflicts. These natural qualities are possessed by women, especially that of non-violence, which are needed by any nation to promote political, social and economic development. The theory also argued that, women have distinctive standards for ethical judgment, and possess lower level of aggressive behavior and greater capacity for creating peaceful co-existence (Ritzer, 2008). This theory has been criticized for being women centered.

\subsection{Traditional Market and Women}

Across the world, especially in Third World countries where communality has not been completely eroded by modern lifestyle, traditional market still plays important roles as the centre of power, justice, equity and socio-political empowerment for women. For instance, Ima Keithel which literally means mother's market in India is essentially for women. In its five hundred years of existence, mother's market in India serves as the forum for exchanging views and taking decisions on important socio-political issues of the state. (The Punch, Newspaper, April 9, 2016).

Traditional markets are usually situated in public areas. In most Yoruba and Igbo communities, they are located very close to the king's palace. Thus, most of the markets are referred to as Oja Oba (the king's market) in south-west Nigeria. Likewise, markets in the south eastern and northern parts of Nigeria are named in honour of ancient heroes as we have Ariara market in Aba and Kurmi market in Kano.

Butter (2011) sees the market place as a space where societal processes are played out on a day-to-day basis. It is where people are confronted with societal issues, where social networks intermingle, and where communication and identity play important roles in creating a feeling of belonging. O’Brian (1997) observed that most of the relationships that take place in the market are based on trust and respect. In the context of this study, a market is taken to be a space for commerce and profit earning. Clarke (1994) characterized people in Nigerian traditional market as mostly women. He observed that women traders play a crucial role in many West African markets. Women dominated market institutions help regulate trade, arguably to the benefit of traders and consumers, both male and female (Clarke 1994).

Traditional markets in Nigeria are hierarchically structured and well organized. For instance, most of the marketplaces in south western Nigeria are built around the king's palace. Each market is headed by 
a female leader called Iyaloja and her male counterpart called Babaloja.

Lawal (2004) enumerates the importance of regulatory body inside a market. He opines that the body safeguards the interests of consumers by ensuring fair pricing, protects its members by outlawing underselling, regulates methods and means of attracting customers, provides appropriate sanitation facilities, and ensures security of life and property in the same localities. The umbrella organization also imposes sanctions on defaulting members. In discharging the aforementioned functions, it liaises with agencies of both the state and local governments on issues of environmental sanitation, street trading and related matters (Lawal, 2004).

Kinoshi and Akintude (2014) related the market structure to a group of elders with no controlling power but charged with the peace and smooth running of the markets. The market women's leaders were needed because trade, which was the primary profession of most women, sustained the community's economy. Therefore, the market women's leaders had the responsibility to keep order.

\subsection{Traditional Market and Arbitration}

The market associations also play crucial roles in conflict prevention and management in the market. Usually, conflicts occur in any of the following ways: (1) between a customer and a trader (2) between a trader and another trader competing for customers (3) power tussle for supremacy among market leaders.

Resolution of these are usually done by the market leaders or arbitrators chosen by them. In democratic dispensations, political leaders always accord and curry the favour of market women especially when they seek elections. Hence, cases that need government intervention are usually resolved before they result in crisis (Interview, June 18, 2016).

Kinoshi and Akintude (2014) contend that other cases such as customer "stealing", card seizure and impersonation may occur. They enumerated two means of settling conflict among market women:

a. The vendors all concurred that "patience conquers all". Even when a vendor engages in "stealing of customers" from another vendor, they try to settle the dispute amicably by exercising patience with each other's exuberance.

b. Any conflict such as customer stealing that cannot be resolved by those directly involved is referred to the local Trade Group Leader first, and usually stops there with the guilty party sanctioned, sometimes with fines or trading privileges suspended for a period. Otherwise, it goes to the overall Trade Group Leader for final resolution.

Olukoju (2006) also enumerates other mechanism for the settlement of disputes within the markets. He avers that the association has devised mechanisms for amicable settlement. Both parties are given a chance to express their grievances and, if the matter was relatively trivial, the guilty party was openly rebuked. If it was a serious matter, the guilty would face sanctions including suspension from the markets for two days or longer, depending on the gravity of the offence. The suspension, known as 
'lockout', forbids the person from displaying her wares for the duration of its enforcement. This translates to a considerable economic loss, which has a direct impact on the livelihood of the guilty party, and thus acts as an effective deterrent against bad behaviour. It is worth noting that the association discourages its members from reporting disputes to the police as the arbitration system is effective in resolving disputes.

\section{Data Presentation and Findings}

Topic: Issues relating to the empowerment of women through the social, economic and political structures institutionalized in the markets.

The gathered data were tested using frequency distribution to describe the demographic characteristics of the respondents. The study research questions were explained using chi square statistics. The findings are presented in tables below.

Table 1. Demographic Distribution of the Respondent

\begin{tabular}{llllll}
\hline \multirow{2}{*}{ Variables } & Response & Ondo & Kano & Abia & Total \\
\cline { 3 - 6 } Sex & Male & 0 & 0 & 0 & 0 \\
& Female & $100(33.3 \%)$ & $100(33.3 \%)$ & $100(33.3 \%)$ & $300(100 \%)$ \\
Age & Total & 100 & 100 & 100 & $300(100 \%)$ \\
& Below 25 years & $7(2.3 \%)$ & $5(1.7 \%)$ & $17(5.7 \%)$ & $29(9.7 \%)$ \\
& 25-34 years & $26(8.7 \%)$ & $24(8 \%)$ & $25(8.3 \%)$ & $75(25 \%)$ \\
& 35-44years & $26(6.7 \%)$ & $37(12.3 \%)$ & $32(10.7 \%)$ & $95(31.7 \%)$ \\
\multirow{5}{*}{ Religion } & 45-54 years & $20(6.7 \%)$ & $21(7 \%)$ & $18(6 \%)$ & $59(19.7 \%)$ \\
& 55-64years & $16(5.3 \%)$ & $11(3.7 \%)$ & $5(1.7 \%)$ & $32(10.7 \%)$ \\
& 65-74years & $4(1.3 \%)$ & $1(0.3 \%)$ & $3(1.1 \%)$ & $8(2.7 \%)$ \\
& 75-84years & $1(0.3 \%)$ & $1(0.3 \%)$ & - & $2(0.7 \%)$ \\
& Total & 100 & 100 & 100 & $300(100 \%)$ \\
& Christianity & $71(23.7 \%)$ & $22(7.3 \%)$ & $91(30.3 \%)$ & $184(61.3 \%)$ \\
\cline { 3 - 5 } Educational & Islam & $24(8 \%)$ & $76(25.3 \%)$ & $9(3 \%)$ & $109(36.3 \%)$ \\
& Traditional & $5(1.7 \%)$ & $2(0.7 \%)$ & - & $7(2.4 \%)$ \\
& Total & 100 & 100 & 100 & $300(100 \%)$ \\
& Below O' level & $43(14.3 \%)$ & $45(15.1 \%)$ & $25(8.3 \%)$ & $113(37.7 \%)$ \\
& O' level & $49(16.3 \%)$ & $40(13.3 \%)$ & $59(19.7 \%)$ & $148(49.3 \%)$ \\
& ND/ NCE & $5(1.7 \%)$ & $10(3.3 \%)$ & $13(4.3 \%)$ & $28(9.3 \%)$ \\
& First Degree/ HND & $3(1 \%)$ & $5(1.7 \%)$ & $3(1 \%)$ & $11(3.7 \%)$ \\
& Total & 100 & 100 & 100 & $300(100 \%)$ \\
\hline
\end{tabular}

From the descriptive table, it was indicated that all the respondents were females $(100 \%)$. They were 100 women each from Ondo, Kano and Abia State. The age distribution revealed that most of the 
respondents across the 3 states were between the ages of 35 and 44 years (31.7\%). And the least group were those above 74 years of age. In terms of religion, it was noted that $61.3 \%$ of the respondents were Christians with 71 from Ondo, 22 from Kano and 91 from Abia State. The sampled respondents that belong to the Islamic religion were 36.3\% with 24 from Ondo, 76 from Kano and just 9 from Abia State. From the 2.4\% that were involved with traditional religion, 5 were from Ondo State, while 2 were from Kano, with none from Abia State. Respondents' educational qualification indicated that most of the respondents generally had O' level as the highest form of their educational qualification, while the least group were those that possessed first degree.

Table 2. Frequency Distribution on the Study Related Questions

\begin{tabular}{|c|c|c|c|c|c|}
\hline \multirow[b]{2}{*}{ Questions } & \multirow[b]{2}{*}{ Response } & \multicolumn{4}{|c|}{ States } \\
\hline & & Ondo & Kano & Abia & Total \\
\hline \multirow{5}{*}{$\begin{array}{l}\text { Do you belong to } \\
\text { any market } \\
\text { women } \\
\text { Association? }\end{array}$} & No & - & - & - & - \\
\hline & Not Sure & - & - & - & - \\
\hline & Yes & 100 & 100 & 100 & 300 (100\%) \\
\hline & & (33.33\%) & (33.33\%) & (33.33\%) & \\
\hline & Total & 100 & 100 & 100 & 300 (100\%) \\
\hline \multirow{4}{*}{$\begin{array}{l}\text { How long have } \\
\text { you been in the } \\
\text { Association }\end{array}$} & $1-10$ years & 85 (28.3\%) & 90 (30\%) & 82 (27.3\%) & 257 (85.7\%) \\
\hline & $11-20$ years & 14 (4.7\%) & 10 (3.3\%) & 14 (4.7\%) & 38 (12.7\%) \\
\hline & 21-30 years & $1(0.3 \%)$ & - & 4 (1.4\%) & 5 (1.7\%) \\
\hline & Total & 100 & 100 & 100 & 300 (100\%) \\
\hline \multirow{4}{*}{$\begin{array}{l}\text { Do you elect your } \\
\text { officers? }\end{array}$} & No & 10 (3.3\%) & 78 (26\%) & 27 (9\%) & 115 (38.3\%) \\
\hline & Not Sure & $9(3 \%)$ & $3(1 \%)$ & 5 (1.7\%) & 17 (5.7\%) \\
\hline & Yes & 81 (27\%) & 19 (6.3\%) & 68 (22.7\%) & 168 (56\%) \\
\hline & Total & 100 & 100 & 100 & 300 (100\%) \\
\hline \multirow{4}{*}{$\begin{array}{l}\text { Are the } \\
\text { association's } \\
\text { officers there for } \\
\text { life? }\end{array}$} & No & 66 (22\%) & 55 (18.3\%) & 84 (28\%) & 205 (68.3\%) \\
\hline & Not Sure & $3(1 \%)$ & $6(2 \%)$ & 4 (1.3\%) & 13 (4.3\%) \\
\hline & Yes & 31 (10.3\%) & 39 (13\%) & 12 (4\%) & 82 (27.3\%) \\
\hline & Total & 100 & 100 & 100 & 300 (100\%) \\
\hline Does & No & 44 (14.7\%) & 57 (19\%) & 44 (14.7\%) & 145 (48.3\%) \\
\hline \multirow{3}{*}{$\begin{array}{l}\text { association have a } \\
\text { bank account? }\end{array}$} & Not Sure & 16 (5.3\%) & 2 (0.7\%) & $6(2 \%)$ & 24 (8\%) \\
\hline & Yes & 40 (13.3\%) & 41 (13.7\%) & $50(16.7 \%)$ & 131 (43.7\%) \\
\hline & Total & 100 & 100 & 100 & 300 (100\%) \\
\hline \multirow{4}{*}{$\begin{array}{l}\text { Does your } \\
\text { association have a } \\
\text { constitution? }\end{array}$} & No & 29 (9.7\%) & 54 (18\%) & 54 (18\%) & 137 (45.7\%) \\
\hline & Not Sure & 21 (7\%) & 37 (12.3\%) & $14(4.7 \%)$ & 72 (24\%) \\
\hline & Yes & 50 (16.7\%) & $9(3 \%)$ & 32 (10.7\%) & 91 (30.3\%) \\
\hline & Total & 100 & 100 & 100 & 300 (100\%) \\
\hline
\end{tabular}

The questions on respondents being a member of any market women association indicated that every respondent was a member of one association within the market. This made them valid respondents for 
the research purpose. The duration of their membership revealed that most of them (85.7\%) had membership of between 1 and 10 years. The question about election of the association officers shows that $56 \%$ agreed that they elect their officers. Among the states, there were differences in their opinion such that in Ondo State, majority of 81 agreed that they elected their officers. In a similar trend, majority (68) respondents from Abia State agreed that they elected their officers. However, most of the respondents from Kano State (78) indicated that they did not elect their officers. Further question revealed that the officers did not serve in their positions for life. $68.3 \%$ responses confirmed this. The response on the question about associations having bank account showed a similar distribution. This was such that $48.3 \%$ disagreed, while $43.7 \%$ agreed, just $8 \%$ were undecided. This showed that a large number of the associations did not operate bank accounts. Lastly in this section, the table showed that most of these associations did not have a constitution. $45.7 \%$ of the respondents indicated that they did not have constitution, $30.3 \%$ said they did, while $24 \%$ were not sure. The variation in the responses was such that majority of those in Ondo State indicated that their association had constitution (50), while 29 disagreed, 21 were not sure. Most of the respondents in Kano and Abia State said that their associations did not have constitutions (54 apiece).

Research Questions 1: Is there any relationship between women's activities in traditional market and political empowerment?

Table 3. Chi Square Summary on the Relationship between Women's Activities in Traditional Market and Political Empowerment

\begin{tabular}{|c|c|c|c|c|c|c|c|c|}
\hline \multirow[b]{2}{*}{ Questions } & \multirow[b]{2}{*}{ Response } & \multicolumn{4}{|c|}{ States } & \multirow[b]{2}{*}{ df } & \multirow[b]{2}{*}{$\mathrm{X}^{2}$} & \multirow[b]{2}{*}{$\mathbf{P}$} \\
\hline & & Ondo & Kano & Abia & Total & & & \\
\hline Does $\quad$ your & No & $20(6.7 \%)$ & $23(7.7 \%)$ & $12(4 \%)$ & 55 (18.3\%) & & & \\
\hline association create & Not Sure & $9(3 \%)$ & 15 (5\%) & $9(3 \%)$ & 33 (11\%) & 4 & 7.756 & $>.05$ \\
\hline avenues for women & Yes & 71 & 62 & 79 & 212 & & & \\
\hline involvement in & & (23.7\%) & (20.7\%) & $(26.3 \%)$ & $(70.7 \%)$ & & & \\
\hline politics? & Total & 100 & 100 & 100 & $300(100 \%)$ & & & \\
\hline politicians & No & $20(6.7 \%)$ & 41 & $7(2.3 \%)$ & $68(22.7 \%)$ & & & \\
\hline involve market & & & (13.7\%) & & & & & \\
\hline women in their & Not Sure & $15(5 \%)$ & $10(3.3 \%)$ & $8(2.7 \%)$ & $33(11 \%)$ & 4 & 38.143 & $<.05$ \\
\hline \multirow[t]{3}{*}{ electioneering? } & Yes & 65 & 49 & 85 & 199 & & & \\
\hline & & $(21.7 \%)$ & (16.3\%) & (28.3\%) & (66.3\%) & & & \\
\hline & Total & 100 & 100 & 100 & $300(100 \%)$ & & & \\
\hline Do members of the & No & 40 & 31 & 35 & 106 & & & \\
\hline
\end{tabular}




\begin{tabular}{|c|c|c|c|c|c|c|c|c|}
\hline association vote en & & $(13.3 \%)$ & $(10.3 \%)$ & $(11.7 \%)$ & (35.3\%) & & & \\
\hline bloc for a favoured & Not Sure & $8(2.7 \%)$ & $11(3.7 \%)$ & $11(3.7 \%)$ & $30(10 \%)$ & 4 & 2.092 & $>.05$ \\
\hline \multirow[t]{3}{*}{ political party? } & Yes & 52 & 58 & $54(18 \%)$ & 164 & & & \\
\hline & & $(17.3 \%)$ & (19.3\%) & & $(54.7 \%)$ & & & \\
\hline & Total & 100 & 100 & 100 & 300 (100\%) & & & \\
\hline \multirow{5}{*}{$\begin{array}{l}\text { Does your } \\
\text { association } \\
\text { encourage women } \\
\text { to make their } \\
\text { voices heard in the } \\
\text { political system of } \\
\text { the society? }\end{array}$} & No & $24(8 \%)$ & $48(16 \%)$ & $14(4.7 \%)$ & 86 (28.7\%) & & & \\
\hline & Not Sure & $13(4.3 \%)$ & $15(5 \%)$ & $10(3.3 \%)$ & 38 (12.7\%) & 4 & 35.746 & $<.05$ \\
\hline & Yes & $63(21 \%)$ & 37 & 76 & 176 & & & \\
\hline & & & $(12.3 \%)$ & (25.3\%) & (58.7\%) & & & \\
\hline & Total & 100 & 100 & 100 & 300 (100\%) & & & \\
\hline \multirow{7}{*}{$\begin{array}{l}\text { Does your } \\
\text { association fight for } \\
\text { the implementation } \\
\text { of policies on } \\
\text { gender equality? }\end{array}$} & No & 28 (9.3\%) & $42(14 \%)$ & 39 (13\%) & 109 & & & \\
\hline & & & & & (36.3\%) & & & \\
\hline & Not Sure & $16(5.3 \%)$ & 38 & $23(7.7 \%)$ & 77 (25.7\%) & 4 & 29.888 & $<.05$ \\
\hline & & & $(12.7 \%)$ & & & & & \\
\hline & Yes & 56 & $20(6.7 \%)$ & 38 & 114 (38\%) & & & \\
\hline & & $(18.7 \%)$ & & $(12.7 \%)$ & & & & \\
\hline & Total & 100 & 100 & 100 & 300 (100\%) & & & \\
\hline
\end{tabular}

The findings revealed that majority of the respondents generally indicated that their association created avenues for women involvement in politics. This was with $70.7 \%$ and the chi square value indicated that there were no significant differences among the states $\left(X^{2}=7.756, p>0.05\right)$. This implies that across the three states under study, market women associations create avenues for women involvement in politics. Also, it was noted that politicians involved market women in their electioneering. This was such that majority of $66.3 \%$ supported it, $11 \%$ were unsure, while just $22.7 \%$ negated. With the significant variation among the states $\left(X^{2}=38.143, \mathrm{p}<0.05\right)$, it was noted that Abia State had the highest respondents affirming that politicians involved market women in their electioneering with 85, 65 confirmed this in Ondo State and 49 concurred in Kano State; with 41 negating from Kano and 10 were not certain. This implies that that women are not carried along in Kano during politicians' electioneering. The table also indicated that most of the respondents (54.7\%) affirmed that members of the association vote en bloc for a favoured political party. With chi square result $\left(X^{2}=2.092, p>0.05\right)$, it indicated that there was no variation among the states, thus across the geographical locations, members of market women association vote en bloc for a favoured political party. It was indicated within the table also that majority of $58.7 \%$ of the total respondents affirmed that their association 
encouraged women to make their voices heard in the political system of the society. With a significant variation across the states $\left(X^{2}=35.746, p<0.05\right)$, it was noted that 63 of the respondents in Ondo State and 76 in Abia State indicated that their association encouraged women to make their voices heard in the political system of the society, while the result in Kano State was different with majority (48) saying that their association did not encourage such. Lastly, it was noted that 38\% of the total respondents said their association fought for the implementation of policies on gender equality, $25.7 \%$ were not sure, while $36.3 \%$ said they did not. With a significant variation among the state $\left(X^{2}=29.888\right.$, $\mathrm{p}<0.05$ ), it was noted that 56 of the respondents from Ondo concurred with the statement; in Kano, 42 respondents negated and 38 were not sure. In Abia state, 38 supported, 39 negated and 23 undecided with the statement that their association fought for the implementation of policies on gender equality.

From the findings, it could be noted that there is relationship between women's activities in traditional market and political empowerment especially in the south west and south east, but the result from the north revealed little involvement of the women in political say.

Research Questions 2: Is there any relationship between women's activities in traditional market and poverty alleviation?

Table 4. Chi Square Summary on the Relationship between Women's Activities in Traditional Market and Poverty Alleviation

\begin{tabular}{|c|c|c|c|c|c|c|c|c|}
\hline \multirow[b]{2}{*}{ Questions } & \multirow[b]{2}{*}{ Response } & \multicolumn{4}{|c|}{ States } & \multicolumn{3}{|c|}{ Chi Square } \\
\hline & & Ondo & Kano & Abia & Total & df & $\mathrm{X}^{2}$ & $\mathbf{P}$ \\
\hline $\begin{array}{l}\text { Does the } \\
\text { government }\end{array}$ & No & $\begin{array}{l}69 \\
(23 \%)\end{array}$ & $\begin{array}{l}32 \\
(10.7 \%)\end{array}$ & $\begin{array}{l}47 \\
(15.7 \%)\end{array}$ & $\begin{array}{l}148 \\
(49.3 \%)\end{array}$ & & & \\
\hline $\begin{array}{l}\text { give financial } \\
\text { support to }\end{array}$ & Not Sure & $9(3 \%)$ & $12(4 \%)$ & 16 (5.3\%) & $\begin{array}{l}37 \\
(12.3 \%)\end{array}$ & 4 & 31.188 & $<.05$ \\
\hline $\begin{array}{l}\text { women in } \\
\text { your }\end{array}$ & Yes & $\begin{array}{l}22 \\
(7.3 \%)\end{array}$ & $\begin{array}{l}56 \\
(18.7 \%)\end{array}$ & $\begin{array}{l}37 \\
(12.3 \%)\end{array}$ & $\begin{array}{l}115 \\
(38.3 \%)\end{array}$ & & & \\
\hline association? & Total & 100 & 100 & 100 & $\begin{array}{l}300 \\
(100 \%)\end{array}$ & & & \\
\hline
\end{tabular}

It was revealed in the result that majority of the respondents in general indicated that the government did not give financial support to women in their association. $49.3 \%$ of the respondents said government did not, $38.3 \%$ said government did, $12.3 \%$ of the respondents were undecided. With the significant chi square value $\left(\mathrm{X}^{2}=31.188, \mathrm{p}<0.05\right)$, it implies that there were differences across the study location, thus looking at the state, it was noted that in Ondo State, most of the respondents (69\%) affirmed that 
government did not give financial support to women in their association. In Imo state, majority of $47 \%$ also said government did not aid women financially, but with just $10 \%$ difference compared to those that said government did. Contrarily, the respondents from Kano state confirmed that the government gave financial support to women in their association. From the above results, it was noted that there was no good relationship between women's activities in traditional market and poverty alleviation programme of government.

Research Questions 3: Is there any relationship between women's activities in traditional market and women's social wellbeing?

Table 5. Chi Square Summary on the Relationship between Women's Activities in Traditional Market and Women's Social Wellbeing

\begin{tabular}{|c|c|c|c|c|c|c|c|c|}
\hline \multirow[b]{2}{*}{ Questions } & \multicolumn{5}{|c|}{ States } & \multicolumn{3}{|c|}{ Chi Square } \\
\hline & Response & Ondo & Kano & Abia & Total & Df & $\mathrm{X}^{2}$ & $\mathbf{P}$ \\
\hline How long does & Within one & 72 (24\%) & 66 (22\%) & 51 (17\%) & 189 (63\%) & & & \\
\hline it take your & day & & & & & & & \\
\hline association to & Within two & 25 (8.3\%) & $28(9.3 \%)$ & 38 & 91 (30.3\%) & 4 & 11.669 & $<.05$ \\
\hline settle disputes & weeks & & & (12.7\%) & & & & \\
\hline \multirow{3}{*}{$\begin{array}{l}\text { among } \\
\text { members? }\end{array}$} & More than & 3 (1\%) & $6(2 \%)$ & $11(3.7 \%)$ & 20 (6.7\%) & & & \\
\hline & one month & & & & & & & \\
\hline & Total & 100 & 100 & 100 & 300 (100\%) & & & \\
\hline If the need to & No & $11(3.7 \%)$ & 37 & $3(1 \%)$ & 51 (17\%) & & & \\
\hline uphold & & & (12.3\%) & & & & & \\
\hline women's rights & Not Sure & $22(7.3 \%)$ & $12(4 \%)$ & $15(5 \%)$ & 49 (16.3\%) & 4 & 47.611 & $<.05$ \\
\hline are channeled & Yes & 67 & 51 (17\%) & 82 & 200 & & & \\
\hline through your & & (22.3\%) & & (27.3\%) & (66.7\%) & & & \\
\hline association, will & Total & 100 & 100 & 100 & 300 (100\%) & & & \\
\hline it be easily & & & & & & & & \\
\hline achieved? & & & & & & & & \\
\hline Does your & No & 32 & 63 (21\%) & 46 & 141 (47\%) & & & \\
\hline association & & (10.7\%) & & (15.3\%) & & & & \\
\hline fight against & Not Sure & $15(5 \%)$ & $18(6 \%)$ & 17 (5.7\%) & $50(16.7 \%)$ & 4 & 26.462 & $<.05$ \\
\hline bills that & Yes & 53 & 19 (6.3\%) & 37 & 109 & & & \\
\hline discriminate & & $(17.7 \%)$ & & (12.3\%) & (36.3\%) & & & \\
\hline against women? & Total & 100 & 100 & 100 & 300 (100\%) & & & \\
\hline
\end{tabular}




\begin{tabular}{llllll|lll}
\hline Has your & No & 53 & $57(19 \%)$ & 50 & 160 & & & \\
association ever & & $(17.7 \%)$ & & $(16.6 \%)$ & $(53.3 \%)$ & & & \\
advocated for & Not Sure & $24(8 \%)$ & 32 & $21(7 \%)$ & $77(25.7 \%)$ & 4 & 10.982 & $<.05$ \\
the enactment & & & $(10.7 \%)$ & & & & \\
of laws against & Yes & $23(7.7 \%)$ & $11(3.7 \%)$ & $29(9.7 \%)$ & $63(21 \%)$ & & \\
$\begin{array}{l}\text { domestic } \\
\text { violence? }\end{array}$ & Total & 100 & 100 & 100 & $300(100 \%)$ & \\
\hline
\end{tabular}

The findings in relation to arbitration showed that $63 \%$ of the respondents said that their association settled disputes within one day, 30.3\% said it did within 2 weeks while $6.7 \%$ said it was done in more than a month. Although, there was a significant variation in the responses $\left(X^{2}=11.669, p<0.05\right)$, the pattern was still in same direction with the highest from Ondo State (73), followed by 66 from Kano and 51 from Abia confirming that disputes are settled within one day. Further finding revealed that majority of the respondents $66.7 \%$ affirmed that if the need to uphold women's rights is channeled through their association, it will be easily achieved. Based on significant variation among the states $\left(X^{2}=47.611, \mathrm{p}<0.05\right)$, it was noted that Abia State had the highest affirmation on the statement with 82 of the respondents, followed by 61 respondents from Ondo State and 51 respondents from Kano. The question about market women association fighting against bills that discriminate against women revealed that $47 \%$ of the respondents disagreed, $16.7 \%$ were not sure while $36.3 \%$ affirmed that the association did. With significant variation among the states $\left(X^{2}=26.462, p<0.05\right)$, it was noted that in Ondo State, majority of 53 agreed that association fought against bills that discriminate against women, 15 were not sure, while 32 did not agree. Contrarily, 63 of the respondents in Kano said the association did not, 18 were not sure, while just 19 agreed. Similarly, 46 in Abia State said the association did not, 17 were not sure, while 37 said it did. This implies the association does not fight against bills that discriminate against women. Finally, it was noted that $53.3 \%$ of the respondents confirmed that their association had never advocated for the enactment of laws against domestic violence. $25.7 \%$ were not sure, while $21 \%$ said they did. Based on significant variation in the responses across the states $\left(\mathrm{X}^{2}=\right.$ 10.982, $\mathrm{p}<0.05$ ), it was noted that this aspect was mostly ignored in the north such that 57 said it was not advocated for. In Ondo state, 53 said it was not advocated for, while 50 of the respondents in Abia said it was not advocated for. From the responses, it could be summed up that relationship between women's activities in traditional market and women's social wellbeing is such that only disputes settlement within the market is well addressed by such associations; much is not being done on issues relating to societal violation, domestic violence or discrimination against women.

Research Questions 4: Is there any relationship between women's activities in traditional market and improvements in women's health? 
Table 6. Chi Square Summary on the Relationship between Women's Activities in Traditional Market and Improvements in Women's Health

\begin{tabular}{|c|c|c|c|c|c|c|c|c|}
\hline \multirow[b]{2}{*}{ Questions } & \multirow[b]{2}{*}{ Response } & \multicolumn{4}{|c|}{ States } & \multicolumn{3}{|c|}{ Chi Square } \\
\hline & & Ondo & Kano & Abia & Total & df & $X^{2}$ & $\mathbf{P}$ \\
\hline $\begin{array}{lr}\text { Have } & \text { NGOs } \\
\text { through } & \text { your }\end{array}$ & No & 75 (25\%) & 3 (1\%) & $\begin{array}{l}80 \\
(26.7 \%)\end{array}$ & $\begin{array}{l}158 \\
(52.7 \%)\end{array}$ & & & \\
\hline Association & Not Sure & 11 (3.7\%) & $6(2 \%)$ & $11(3.7 \%)$ & $28(9.3 \%)$ & 4 & 183.490 & $<.05$ \\
\hline $\begin{array}{l}\text { enlightened you } \\
\text { about the evil }\end{array}$ & Yes & $14(4.7 \%)$ & $\begin{array}{l}91 \\
(30.3 \%)\end{array}$ & $9(3 \%)$ & 114 (38\%) & & & \\
\hline $\begin{array}{l}\text { effects of giving } \\
\text { out underage } \\
\text { girls in marriage? }\end{array}$ & Total & 100 & 100 & 100 & 300 (100\%) & & & \\
\hline $\begin{array}{l}\text { Do state Health } \\
\text { officials reach }\end{array}$ & No & $\begin{array}{l}68 \\
(22.7 \%)\end{array}$ & $2(0.7 \%)$ & $\begin{array}{l}79 \\
(26.3 \%)\end{array}$ & $\begin{array}{l}149 \\
(49.7 \%)\end{array}$ & & & \\
\hline out to you about & Not Sure & $12(4 \%)$ & 5 (1.7\%) & $14(4.7 \%)$ & 31 (10.3\%) & 4 & 181.612 & $<.05$ \\
\hline the menace of & Yes & 20 (6.7\%) & 93 (31\%) & 7 (2.3\%) & $120(40 \%)$ & & & \\
\hline $\begin{array}{l}\text { vesico vaginal } \\
\text { fistula (VVF) and } \\
\text { how to prevent } \\
\text { it? }\end{array}$ & Total & 100 & 100 & 100 & 300 (100\%) & & & \\
\hline Does $\quad$ your & No & 30 (10\%) & 30 (10\%) & $6(2 \%)$ & 66 (22\%) & & & \\
\hline Association & Not Sure & $6(2 \%)$ & 25 (8.3\%) & $6(2 \%)$ & 37 (12.3\%) & 4 & 51.110 & $<.05$ \\
\hline $\begin{array}{l}\text { encourage you to } \\
\text { allow your }\end{array}$ & Yes & $\begin{array}{l}64 \\
(21.3 \%)\end{array}$ & 45 (15\%) & $\begin{array}{l}88 \\
(29.3 \%)\end{array}$ & $\begin{array}{l}197 \\
(65.7 \%)\end{array}$ & & & \\
\hline $\begin{array}{l}\text { children to take } \\
\text { polio-vaccine? }\end{array}$ & Total & 100 & 100 & 100 & 300 (100\%) & & & \\
\hline your & No & 51 (17\%) & 51 (17\%) & $24(8 \%)$ & 126 (42\%) & & & \\
\hline Association been & Not Sure & 17 (5.7\%) & 33 (11\%) & $21(7 \%)$ & 71 (23.7\%) & 4 & 39.819 & $<.05$ \\
\hline $\begin{array}{l}\text { reached in the } \\
\text { campaign against }\end{array}$ & Yes & $\begin{array}{l}32 \\
(10.7 \%)\end{array}$ & $16(5.3 \%)$ & $\begin{array}{l}55 \\
(18.3 \%)\end{array}$ & $\begin{array}{l}103 \\
(34.3 \%)\end{array}$ & & & \\
\hline $\begin{array}{l}\text { female genital } \\
\text { mutilation } \\
\text { (FGM)? }\end{array}$ & Total & 100 & 100 & 100 & 300 (100\%) & & & \\
\hline $\begin{array}{l}\text { Has your } \\
\text { Association been }\end{array}$ & No & $\begin{array}{l}55 \\
(18.3 \%)\end{array}$ & $\begin{array}{l}61 \\
(20.3 \%)\end{array}$ & 60 (20\%) & $\begin{array}{l}176 \\
(58.7 \%)\end{array}$ & & & \\
\hline
\end{tabular}




\begin{tabular}{llllll|lll}
\hline organizing & Not Sure & $14(4.7 \%)$ & $15(5 \%)$ & $10(33 \%)$ & $39(13 \%)$ & 4 & 2.441 & $>.05$ \\
women & Yes & 31 & $24(8 \%)$ & $30(10 \%)$ & $85(28.3 \%)$ & & & \\
enlightenment & & $(10.3 \%)$ & & & & \\
programmes? & Total & 100 & 100 & 100 & $300(100 \%)$ & & \\
Does your & No & $23(7.7 \%)$ & 34 & $15(5 \%)$ & $72(24 \%)$ & & & \\
Association & & & $(11.3 \%)$ & & & & \\
campaign against & Not Sure & $10(3.3 \%)$ & $24(8 \%)$ & $12(4 \%)$ & $46(15.3 \%)$ & 4 & 23.974 & $<.05$ \\
Rape and Sexual & Yes & 67 & $42(14 \%)$ & 73 & 182 & & & \\
Assault & & $(22.3 \%)$ & & $(24.3 \%)$ & $(60.7 \%)$ & & & \\
Women? & & Total & 100 & 100 & 100 & $300(100 \%)$ & & \\
\hline
\end{tabular}

The findings on relevance of market women association to their health revealed that $52 \%$ of the respondents said that NGOs had not enlightened them through their association about the evil effects of giving out underage girls in marriage. With a significant variation among the states $\left(X^{2}=183.490, p<\right.$ 0.05), it was noted that in Abia State, majority of 80 said NGOs did not enlighten them on the evil of underage girl-marriage. Similarly, majority in Ondo State said NGOs did not; on the contrary, 91 of the respondents from Kano agreed that that through their Association, NGOs had enlightened them about the evil effects of giving out underage girls in marriage. In line with the earlier observed finding, it was also indicated that state Health officials had not reached out to them about the menace of vesico vaginal fistula (VVF) and how to prevent it. This was with $49.7 \%$ responses and with a significant variance among the states $\left(\mathrm{X}^{2}=181.612, \mathrm{p}<0.05\right)$, it was noted that the observation from the summed total was contributed based on responses from Ondo (68) and Abia (79) states where the State Health officials did not reach out to them about the menace of VVF and how to prevent it. However, they did in Kano with 93 of the respondents confirming it. The findings from the table also confirmed that their association encouraged them to allow their children to take polio-vaccine. This was with $65.7 \%$ responses and based on the significant variation observed $\left(X^{2}=51.110, p<0.05\right)$, the differences among the states were observed. The respondents from Abia State had the highest affirmation to the statement that that their association encouraged them to allow their children to take polio-vaccine with 88 respondents. This was followed by respondents from Ondo with 64 while just 45 agreed from Kano.

Further questions on health revealed that $42 \%$ of the respondents indicated that their association had not been reached in the campaign against female genital Mutilation (FGM). The variation among the states $\left(\mathrm{X}^{2}=39.819, \mathrm{p}<0.05\right)$ is such that those from Ondo and Kano confirmed the general findings by $51 \%$ each that their association had not been reached in the campaign against FGM, while Abia State had a different experience with $55 \%$ of the respondents indicating that their association had been reached in the campaign against FGM. On the organization of women enlightenment programmes, it 
was noted that majority of the respondents generally (58.7\%) said their association had not been organizing women enlightenment programmes. Since there was no variation among the states $\left(X^{2}=2.441, \mathrm{p}>0.05\right)$, it implies that the association in all states had not been organizing women enlightenment programmes. Finally, the study revealed that market women associations campaigned against rape and sexual assault on women. This is with $60.7 \%$ affirmation by respondents. Although, there was significant variation among the states responses $\left(X^{2}=23.974, p<0.05\right)$, the responses were still in similar directions. This was such that those in Abia State had the highest confirmation with 73, followed by Ondo State with 67, while Kano had just 42 of its respondents affirming that their associations campaigned against rape and sexual assault on women.

\section{Conclusion}

This study reveals how market women associations serve as channels through which politicians reach women for their votes. Women are involved in politics to the extent that they exercise their franchise during elections. However, the political space will be enriched if more women contest and occupy legislative seats.

The arbitration system entrenched by market women associations is very effective. It serves as an alternative dispute resolution that allo ws the wheels of commerce to move unhindered.

Furthermore, market women associations are yet to give adequate consideration to health issues like vesico vaginal fistula and female genital mutilation being diseases that afflict women only. It is time the associations began to enlighten their members on these and other medical matters so that their members can enjoy good health.

There is also need for the association to promote legislations that protect women against domestic violence and sexual assault. Besides, women should be regularly educated on how they can protect themselves and seek redress when they encounter violent men.

Finally, market women associations function primarily to promote commercial interests of their members. In addition, they have evolved to serve other purposes which have helped in stabilizing the society. As they are expected to improve in the identified areas, there are lessons that other social groups can learn from them too.

\section{References}

Awe, B. (1992). Nigerian women in historical perspectives. Ibadan: Sankore.

Ayittey, G. B. N. (1991). Indigenous African institutions. USA: Transnational Publishers Inc.

Clarke, G. (1994). Onions are my husband: survival and accumulation by West African market Women. Chicago and London: University of Chicago Press. https://doi.org/10.7208/chicago/9780226107769.001.0001 
Good, C. M. (1976). Markets and Marketing. In C. K. Gregory, \& J. E. Newman (Eds.), Contemporary Africa geographical and change. New Jersey: Prentice-Hall Inc.

Hodder, B. W., \& Ukwu, U. I. (1969). Markets in West Africa. Ibadan: University press.

Ikpe, E. B. (1997). The Role of Women in National Development. In A. Osunkotun, \& A. Olukoju (Eds.), Nigerian peoples and cultures. Ibadan: Davidson Press.

Jinadu, L. A. (2002). Ethnic conflict and federalism in Nigeria. ZEF Bonn, discussion paper no. 49.

Kinoshi, T., \& Akintude, S. O. (2014). Leveraging ICT and indigenous knowledge in the Nigerian flea market business. Singaporean Journal of Business Economics and management Studies, 2(11), 155-168. https://doi.org/10.12816/0006790

Lawal, A. (2004). Markets and Street Trading in Lagos. In T. Falola, \& J. S. Steven (Eds.), Nigerian Cities (pp. 237-254). Trenton, NJ: Africa World Press.

Mabogunje, A. L. (2008). Migration policy and regional development in Nigeria. Nigerian Journal of Economics and Social studies, 12(2), 243-262.

Madubuike, S. C., \& Solomon, V. A. (2007). Gender images: The deification of motherhood in Igbo society. In S. Afonja (Ed.), Beyond our imaginations: African women's realities. Ibadan: Spectrum Books Ltd.

Mba, N. (1989). Nigerian women mobilized: women's political activity in Southern Nigerian. California: University of California.

O’Brian, R. (1997). Maya market women's sales strategies in a stationary artisanal market and responses to changing gender relations in Highland Chiapas, Mexico. Working paper series.261, Women in International Development, Michigan State University.

Olukoju, A. (2006). Actors and institutions in urban politics in Nigeria: Agege (Lagos) since the 1950s (pp.153-178). Council for the Development of Social Science Research in Africa \& Association of African Historians Afrika Zamani, Nos. 13 \& 14, 2005-2006. 